\title{
Human Resource Management Practices (Training and Development, Performance Appraisal, and Reward System) as Latent Predictors of Job Performance: A Technology-Based Model Development
}

\author{
Hemalatha Somu* \\ Graduate School of Business \\ Universiti Sains Malaysia \\ Penang, Malaysia. \\ pkv7599@gmail.com \\ Hafinas Halid \\ Graduate School of Business \\ Universiti Sains Malaysia \\ Penang, Malaysia. \\ hafinashalid07@gmail.com
}

\author{
Aizzat Mohd Nasurdin \\ School of Management \\ Universiti Sains Malaysia \\ Penang, Malaysia. \\ aizzat@usm.my \\ Yu Yin Lim \\ Graduate School of Business \\ Universiti Sains Malaysia \\ Penang, Malaysia. \\ yuyinlim@gmail.com
}

\author{
Cheng Ling Tan \\ Graduate School of Business \\ Universiti Sains Malaysia \\ Penang, Malaysia. \\ tanchengling@usm.my
}

\begin{abstract}
The article proposes Human Resource Management Practices (HRMPs) to enhance employee's job performance. Researchers and practitioners have paid considerable attention to job performance because performance at individual level has desirable consequences on an organizations. From a strategic perspective, since organizations have a major influence on their human capital, incorporating organizational-level elements such HRMPs may facilitate our understanding of the interlocking relationships between HRMPs and employee performance. The aim of this paper is to review the extant literature and propose a model linking HRMPs (training and development, performance appraisal, and reward system) with job performance. Also discussed is the electrical and electronics sector in the Malaysian manufacturing context to support the proposed linkage. Findings from the review were then utilized to develop a research model for further testing. The key findings emerging from this review suggest that three HRMPs (training and development, performance appraisal, and reward system) are the key possible predictors of job performance that can strengthen or weaken HRMPsperformance relationships. These links may prompt organizations to adopt more focused strategies to enhance their employees' job performance.
\end{abstract}

Keywords: human resource management practices, job performance, performance appraisal, reward system, task performance, training and development

\section{INTRODUCTION}

Nowadays, the visionary idea of Industry 4.0 or other synonyms like Smart Manufacturing, Smart Production or Industrial Internet, to name a few, have been promoted steadily by different actors to describe the trend towards digitisation, automation and the increasing use of ICT in the manufacturing environment [1]. In this context, the term
Industry 4.0 comprises a variety of technologies to enable the development of a digital and automated manufacturing environment as well as the digitisation of the value chain. This results in improvements in product quality and a decrease of time to-market as well as improvements in enterprise performance $[2,3]$.

Intense competition in today's business environment has necessitated the need for organizations to operate their activities strategically by focusing on the lowest possible cost. To achieve better resource utilization, these companies have emphasised on the quality of their products or services in order to meet customers' expectations.

\section{A. Background of Study}

Malaysia's manufacturing sector is one of the leading sectors in the country and has contributed to the growth of the economy, in terms of manufacturing exports, employment, and investments [4] the manufacturing sector recorded total investments of RM63.7 billion, representing an increase of $8.9 \%$ from RM58.5 billion in 2016. On a specific note, Malaysia's electronic and electrical (hereafter labelled as E\&E) industry has been a significant contributor to the nation's economy, having been identified in the 11 th Malaysia Plan as one of the ' $3+2$ ' catalytic sectors. In 2010, the E\&E industry contributed $55.9 \%$ of the country's manufacturing export and created employment opportunities for 296,870 people [4]. In 2017, the industry attracted the greatest amount of foreign investments (RM8.2 billion, or $84.5 \%$ of all investments in the industry), mostly from Singapore, the Netherlands, Japan, and Germany. The success of the E\&E industry was further evidenced by it being the country's largest export earner in 2017, amounting to a total of RM343 billion and accounting for $36.7 \%$ of the total value of exports. From 2017 to 2018, the investment relating to the $\mathrm{E} \& \mathrm{E}$ industry amounted to 
RM58.6 billion representing 92\% of the total investments approved in this manufacturing sector [4]. This situation necessitates a huge number of skilled workers, particularly engineers, who can champion new product design and development and implement innovative manufacturing activities. Thus, given the fact that engineers serve as the backbone of a manufacturing firm, their job performance would have a significant impact on a firm's performance and success. In this regard, the strategic looking into Human Resource Management Practices (here after labelled as HRMP) training and development, performance appraisal and reward system is considered to be able to bring out the best in employees [5,6,7]. A review of the extant literature seems to suggest three specific these three factors that could significantly affect job performance. These, (1) training and development, (2) performance appraisal, and (3) reward system $[5,6,7]$.

\section{B. Problem Statement}

The business biosphere is becoming more economical, and with speedy changes over the centuries, the setting has led to greater instability and unpredictability. Although Malaysia's manufacturing sector is one of the key contributors to its economy, the country's manufacturing ranking in comparison to other countries is still far behind. But based on growth in developing Asia it is forecast to dip slightly. The gross domestic product (GDP) in the region will expand by $5.7 \%$ in 2016 and 2017, decelerating from $5.9 \%$ in 2015 in a difficult and uncertain global environment. This scenario implies that the country's growth also slight dipped and need improvement (Asian Development Outlook, the 2016). Based on Asian Development Outlook report as depicted in Fig. 1, 2016 trends in industrial production reflect a tepid economic expansion in export-oriented economies. Based on industrial production index of Asia, Malaysia's rate was not stable and inconsistent. Based on the period from 2014 until 2016, Malaysia production index decreased, thus we need look into it and must improve our production index. Malaysia needs to improve economically in order to compete with other countries particularly in the manufacturing sector.

Besides that, according to World Competitiveness Yearbook (WCY) for years 2013-2018, Malaysia was ranked 22nd out of 63 countries (Table 1), indicating therefore that even though the manufacturing sector is one of the leading sectors in Malaysia, it is still lagging behind other countries. This highlights an area that needs to be improved. To compete with other countries, Malaysia needs to implement R\&D activities for the development or innovation of new products or systems. These efforts nevertheless require every employee in the manufacturing sector to perform better to increase productivity.

Table 1 revealed that the manufacturing performance in Malaysia is still lagging. Probably due to the declining manufacturing productivity. One avenue to address this shortcoming would be through the improvements of job performance by the employees in the Malaysian manufacturing industry. Given the above setting, there is an urgent need for the Malaysian manufacturing sector to reenergize itself and become more productive and advanced. These outcomes can be accomplished by looking into HRMPs such as training and development, performance appraisal and reward system [8]. It has been widely acknowledged that employing supportive HRMPs can lead to improvements in employee's attitudes and behaviours [8]. One form of work behaviour is job performance.

\section{Research Question}

Do Human resource management practices like the dimensions of (training and development, performance appraisal and reward system) enhance job performance?

\section{Purpose of Study}

On the basis of the above-mentioned discussion, the purpose of this paper is to propose a model linking selected human resource management practices dimensions of (training and development, performance appraisal and reward system) to enhance the job performance.

\section{MATERIALS AND METHODS}

\section{A. Literature Review}

1. Human Resource Management Practices (Training and Development, Performance Appraisal and Reward System) and Job Performance

HRMPs are instruments that can facilitate increasing the performance of an organization through its employees [9]. HRMPs have been noted to consist of a set of policies and practices, such as extensive training, incentive compensation system, employment security, selective staffing, employee participation in decision making, and career developmental activities [3].Firms that implement HRMPs place greater emphasis on their employees' personal development and value. HRMPs could foster a work environment that aims to motivate, develop, and manage employees to give their best to support organizational goals. Investing in employees' knowledge, skills, and abilities, therefore, can lead to improved individual work outcomes and, eventually, heightened organizational outcomes. In this study, three HRMPs are identified: training and development, performance appraisal, and reward system.

Organizations use HRMPs to develop employee knowledge, skills, and abilities and to enhance employee motivation by providing comprehensive recruitment and selection procedures, incentive compensation, performance management systems, and extensive employee involvement and training [10]. Many human resource studies have demonstrated the universal applicability of HRMPs in improving organizational outcomes through promoting employee involvement, commitment, or performance [11,12]. Empirical evidence reveal that employing supportive HRMPs can lead to improvement in employee's job performance $[5,6,7]$. Hence, it is proposed that:

Proposition 1: HRMPs (i.e. training and development, performance appraisal, and reward system) will be positively related to job performance.

\section{Training and Development and Job Performance}

Training and development (T\&D) focuses on identifying, assuring, and helping to develop, through 
planned learning, the key competencies that enable individuals to perform their current jobs. An effective training program can facilitate the development of a more conducive learning environment for the workforce and train them to cope with upcoming challenges more easily and timely. Training generally leads to higher levels of employees' job performances, which in turn, can have a positive effect on their productivity. Therefore, training is essential for the expansion of personnel's knowledge and skills in order to contribute more efficiently to a team. For these reasons, organization conducts extensive training for their employees in order to improve their current level of job performance. Development programs are meant to improve employees' future performance [13].

In an era of rapid high-technology changes, all indicators have shown the move of technological innovation will continue to accelerate in the future [14]. In an environment of rapid change, it is clear that an individual must be able to adapt to meet new challenges. The evolvement of technologies has continued alter the nature of work tasks, requiring employees to learn new knowledge and skills to perform their jobs. Training and development has been the formal efforts within organizations to improve their employee's' performance and self-fulfilment, particularly the use of different educational programs and procedures [6]. When employees recognize their organization's interest in them through the offering of training programs, they in turn would apply their best efforts to achieve their organizational goals and high performance.

To perform assigned task effectively, employees need to go through proper training and development courses conducted by trained employees. Training is an important exercise that can facilitate achievement of organizational goals i.e. sustainable competitive advantages over competitors and grasp significant market share [15]. Without proper training, employees, both new and current, do not receive the required information that enables them to develop the skill sets necessary for accomplishing their tasks at their maximum potential. Therefore, training is a necessity in the workplace. Without it, employees do not have a firm grasp of their responsibilities or duties. In the present business environment, training and development are two of the main key HPHRMPs that can enhance employee primary skills, abilities, superior knowledge, positive attitude and behavior [16]. Training can also develop employees' high performance and increase an organization's productivity [17]. Thus, training and development should include programs, seminars, and workshops that can develop and enhance employee knowledge, skills, and abilities. Training can be one of the essential methods for helping every employee to receive the new knowledge and skills needed to retain the performance level in a rapidly changing work environment.

To attain sustainable competitive advantage, organization depends on skilled workforce and product development and the sense of potential sacrifice associated with leaving. [18] Suggest that in order for employees to contribute and provide a sustained competitive advantage to their organizations, they have to grasp more market share and improving profitability. The management of organization can assess the effectiveness of training and development programs by comparing the costs of conducting training programs and contribution of skilloriented training programs into organizational productivity [18]. Organizations conduct extensive training to develop their employees, achieve strategic position over competitors, and improve the level of employee job performance [15]. Thus, training and development is considered a predictor of perceived job performance. The foregoing discussion leads to the following sub-proposition:

Proposition 1 (a): Training and development will be positively related to job performance.

\section{Performance Appraisal and Job Performance}

Performance appraisal is a process of reviewing a worker's duties and goals and is a critical measurement for a worker and an organization [19]. A performance appraisal provides a formal opportunity to categorize, assess, and nurture worker performance [20]. Employee job performance assessment can be conducted based on selfassessment, or based on the perspectives of human resource administrators, supervisors, and co-workers [10].

The performance appraisal process is a formal, yearlong mechanism for communicating to an employee the extent to which he/she is meeting job responsibilities. Performance appraisal concerns increasing an employee's awareness of how they are valued within organization, and this awareness is likely to result in effective commitment [21]. A performance appraisal can help employees (1) to improve their performance by receiving specific feedback about the need for development and (2) to continue to excel by receiving positive reinforcement. This types of feedback may be essential to improve the performance of employees at all levels [22]. Workers' perceived fairness of their performance appraisal can adversely influence their attitude and performance [23]. When an employee feels that an unjust appraisal of personal performance has occurred, he or she may feel driven to behave in unsatisfactory or unexpected ways, causing decreased performance levels and disruption in processes [23,24,25]. Thus, the sub proposition is as follows:

Proposition 1(b): Performance appraisal will be positively related to job performance.

\section{Reward System and Job Performance}

Reward system is the most common HPHRMPs used to acknowledge and compensate sales associates for their good job performance. A reward system consists of both incentive and recognition programs. Incentive is the financial inducement that an organization offers to employees in exchange for contributing to sales figures, quality, and customer service. It is important to note that incentives are distinct from pay and remuneration practices (salary or wages). In contrast, recognition refers to the identification of a "job well done," hence representing a nonfinancial means of appreciating and acknowledging a sales associate's contributions to sales figures, quality, and customer service. HRMPs should also focus on a reward system to motivate an employee's performance that is consistent with a firm's strategy [7]. According to [8], the effectiveness of an organization's performance and reward system have an impact on moral and productivity. Many organizations have found that far from complementing the 
stated aims of a business, their performance and reward systems were actually causing counter-productive behaviour. On the one hand the "path-goal model", absolutely explains the relationship between reward system and employee job performance. The "path-goal model" concept states that "if a worker sees high productivity as a path leading to the attainment of one or more of his personal goals, he will tend to be a high producer. Conversely, if he sees low productivity as a path to the achievement of his goals, he will tend to be low producer. In other words, the employee would be motivated to expend a greater amount of effort in his work if he felt his previous effort had resulted in his receiving rewards"' [20].

A reward management system contains an organization's policies, processes and practices for rewarding its employees in accordance with their contribution, abilities and artifice. It is progressed within an organization's reward philosophy, strategies and policies, and includes agreements in the form of processes, practices, structures and procedures which will provide appropriate types and levels of pay, benefits and other forms of reward. Employee job performance is originally what an employee does or does not do. The performance of employees could include: quantity of output, quality of output, timeliness of output, presence at work, cooperativeness. A reward system includes both financial (extrinsic) and non-financial (intrinsic) rewards. Financial rewards are salary increase, bonus system, perquisite etc. Non-financial reward include promotion and title, authority and responsibility, education, appreciation and praise, certificate and plague, participation to decisions, vacation time, comfort of working place, social activities, feedback, flexible working hours, design of work, recognition, social rights etc. [5]. The foregoing discussion prompted the following proposition:

Proposition 1(c): Reward system will be positively related to job performance.

\section{B. Research Methods}

This research was grounded on a solid theoretical framework that combines secondary data. A systematic literature review was conducted using as archival method to review the articles related to HRMPs (training and development, performance appraisal and reward system) predictors, and job performance as cited in database such as Emerald, ProQuest and Science Direct. The secondary data were analysed to construct a solid theoretical structure as the foundation for this study. Past literature was looked into it for archival method.

\section{Conceptual Framework}

Based on the preceding discussion, a conceptual framework is proposed as depicted in Fig. 2. Human resource management practices with dimensions (training and development, performance appraisal and reward system) are assumed to predict job performance within the context of the R\&D engineers in manufacturing sector. Job performance, for this study, focuses on task performance.

\section{Results}

As discussed in the literature review, this study proposes an integrated framework (Fig. 2), which highlights the HRMPs predictors as the independent variables and, job performance as the dependent variable. Job performance focused on task performance R\&D engineers.

\section{DISCUSSION AND CONCLUSION}

The present paper discusses the importance $R \& D$ engineer's job performance and how the three specific human resource management practices (training and development, performance appraisal and reward system) can help engineers, particularly in the E\&E manufacturing, to become highly motivated in their work and deliver higher job performance. Findings that facilitated the development of the model were derived from the review of secondary information through a library search engine. The paper provides some practical insights on the use of selected HRMPs in influencing job performance. Because motivation is important in strengthening the HRMPsperformance relationships, we suggest that manufacturing forms strive to constantly motivate their current employees apart from placing emphasis on recruiting highly motivated and engaged candidates. Highly motivated and highperforming workers represent a key source of competitive advantage for an organization. Given the intense challenges faced by the manufacturing sector globally and more so in Malaysia, there is an urgent need for Malaysian manufacturing firms to stimulate their workforce to become highly motivated and high performers. The firms need to pay attention to their HRMPs in order to create a supportive work environment that will bring out the best in their employees in terms of positive attitudes and behaviors.

\section{REFERENCES}

[1] H. Lasi, P. Fettke, H.-G. Kemper, T. Feld, and M. Hoffmann, “Industrie 4.0,” Bus. Inf. Syst. Eng., vol. 6, no. 4, pp. 239-242, Jun. 2014.

[2] R. Schmidt, M. Möhring, R.-C. Härting, C. Reichstein, P. Neumaier, and P. Jozinović, "Industry 4.0 - Potentials for Creating Smart Products: Empirical Research Results," in Business Information Systems, pp. 16-27, 2015.

[3] M. Brettel, N. Friederichsen, M. Keller, and M. Rosenberg, "How Virtualization, Decentralization and Network Building Change the Manufacturing Landscape: An Industry 4.0 Perspective," Int. J. Mech. Aerosp. Ind. Mechatron. Manuf. Eng., vol. 8, no. 1, 2014.

[4] MIDA [Malaysian Investment Development Authority], Industries in Malaysia, (2016, 2018).

[5] A. Du Plessis, N. Douangphichit, and P. Dodd, "HRM in relation to employee motivation and job performance in the hospitality industry," International Business Conference (IBC), 2015.

[6] T. Sakikawa, K. Chaudhuri, and N.A. Arif, "A study on management practices and manufacturing performance in India and Malaysia," Journal of Asia Business Studies, vol. 11(3), pp. 278295, 2017.

[7] K. Mason, "The impact of HR practices on employee motivation and performance [dissertation]," Cardiff Metropolitan University, 2017.

[8] O. C. Hee and K. R. Jing, "The Influence of Human Resource Management Practices on Employee Performance in the Manufacturing Sector in Malaysia," International Journal of Human Resource Studies, vol. 8, no. 2, pp. 129-147, 2018.

[9] D. E. Guest, J. Paauwe, and P. Wright, HRM and Performance: Achievements and Challenges, John Wiley \& Sons, 2012. 
[10] T. C. Brown, "Effectiveness of distal and proximal goals as transfer - of - training interventions: A field experiment," Human Resource Development Quarterly, vol. 16(3), pp. 369-387, 2005.

[11] R. D. Allen, M.A. Hitt, and C.R. Greer, "Occupational stress and perceived organizational effectiveness in formal groups: an examination of stressor level and stressor type", Personnel Psychology, vol. 35, no. 2, pp. 359-70. 1982.

[12] P. C. Patel, J. M. Jensen, and J. G. Messersmith, "High-performance work systems and job control: Consequences for anxiety, role overload, and turnover intentions," Journal of Pulakos, 2013.

[13] G. P. Latham, "Goal setting: A five-step approach to behavior change," Organizational Dynamics, vol. 32, no. 3, pp. 309-318. 2003.

[14] K. E. Plamondon, S. Arad, and M.A. Donovan, "Adaptability in the workplace: Development of a taxonomy of adaptive performance," Journal of applied psychology, vol. 85, no. 4, pp. 612, 2000.

[15] J. B. Barney, Firm resources and sustained competitive advantage, In Economics Meets Sociology in Strategic Management (pp. 203227), Emerald Group Publishing Limited, 2000.

[16] S. Tangthong, J. Trimetsoontorn, and N. Rojniruntikul, "HRM Practices and Employee Retention in Thailand," International Journal of Trade, Economics and Finance, vol. 5, no.2, 2014.

[17] A. Ul-Ameeq and F. Hanif, "Impact of training on employee's development and performance in hotel industry of Lahore Pakistan," Journal of Business Studies Quarterly, vol. 4, no. 4, pp. 68-82, 2013.

[18] T. R. Zenger and C. R. Marshall, "Determinants of incentive intensity in group-based rewards," Academy of Management Journal, vol. 43, no. 2, pp. 149-163, 2000.
[19] J. R. Hackman and G. R. Oldham, "Motivation through the design of work: test of a theory", Organizational Behavior and Human Performance, vol. 16, no. 2, pp. 250-279, 1976.

[20] P. Güngör, "The relationship between reward management system and employee performance with the mediating role of motivation: A quantitative study on global banks," Procedia-Social and Behavioral Sciences, vol. 24, pp. 1510-1520, 2011.

[21] P. E. Levy and J.R. Williams, "The social context of performance appraisal: A review and framework for the future," Journal of management, vol. 30, no.6, pp. 881-905, 2004.

[22] B. G. Mani, "Performance appraisal systems, productivity, and motivation: A case study," Public Personnel Management, vol. 31, no. 2, pp. 41-159, 2002.

[23] P. A. Heslin, and D. VandeWalle, "Performance appraisal procedural justice: The role of a manager's implicit person theory," Journal of Management, vol. 37, no. 6, pp. 1694-1718, 2011.

[24] B. Kuvaas, "The interactive role of performance appraisal reactions and regular feedback," Journal of Managerial Psychology, vol. 26, no. 2, pp. 123-137, 2011.

[25] M. Shaharyar, M. A. Baloch, M. A. Tariq, S. Mushtaq, and A. Mushtaq, "Impact of performance appraisal on employee performance," Journal of Resources Development and Management, vol. 3, no. 22, pp. 22-24. 2014.

[26] A. E. Oke, O. T. Ibironke, and O. A. Bayegun, "Appraisal of reward packages in construction firms: A case of quantity surveying firms in Nigeria," Journal of Engineering, Design and Technology, vol. 15, no. 6, pp. 722-737, 2017.

\section{APPENDIX}

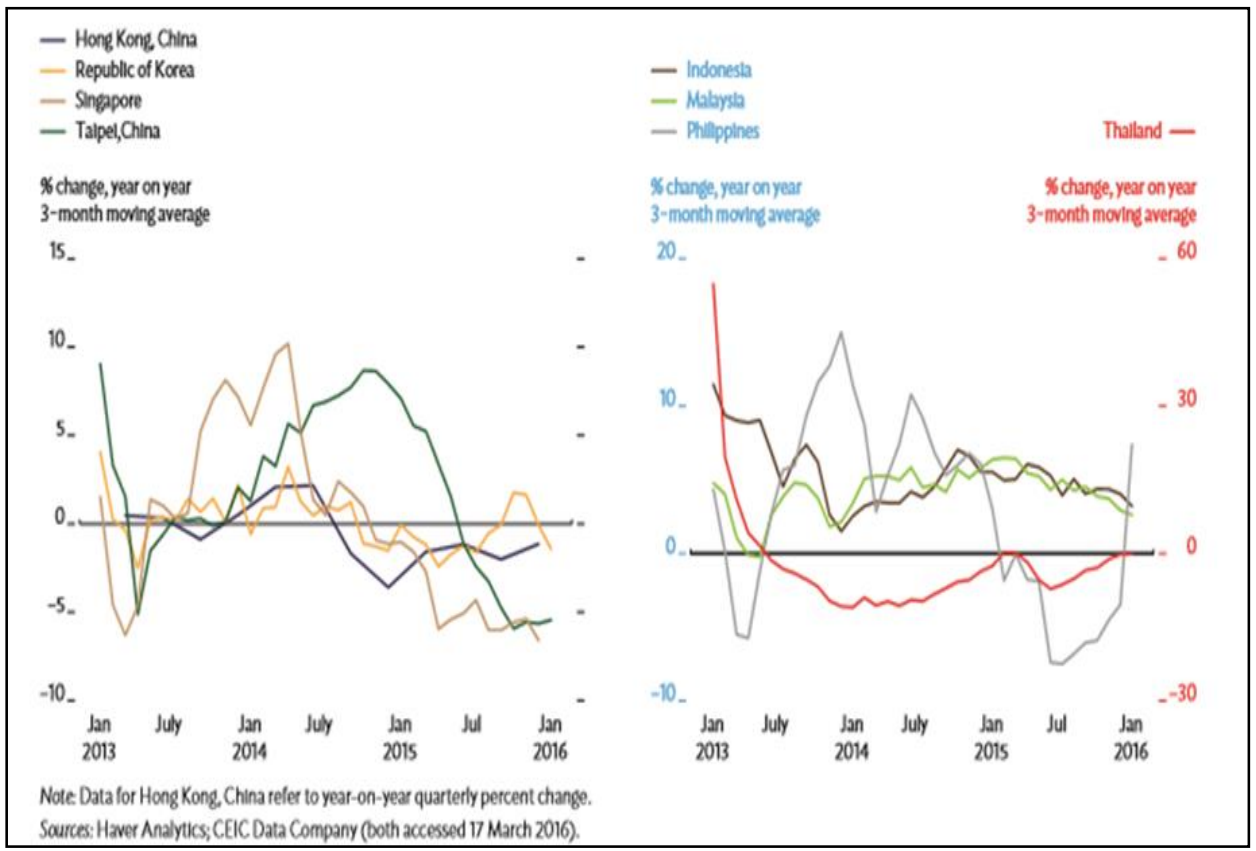

Fig. 1. Industrial Production Index

Source: Asian Development Outlook, 2016. 


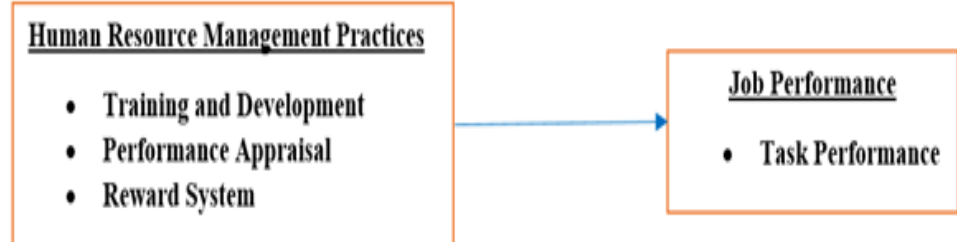

Fig. 2. Conceptual Framework

TABLE 1. WORLD COMPETIVENESS YEARBOOK, 2013-2018

\begin{tabular}{|c|c|c|c|c|c|c|c|c|c|c|c|c|c|}
\hline \multirow{2}{*}{ No } & \multirow{2}{*}{ Country } & \multicolumn{2}{|c|}{2018} & \multicolumn{2}{|c|}{2017} & \multicolumn{2}{|c|}{2016} & \multicolumn{2}{|c|}{2015} & \multicolumn{2}{|c|}{2014} & \multicolumn{2}{|c|}{2013} \\
\cline { 3 - 16 } & & Rank & Score & Rank & Score & Rank & Score & Rank & Score & Rank & Score & Rank & Score \\
\hline 1 & USA & 1 & 100.00 & 4 & 98.66 & 3 & 97.88 & 1 & 100.00 & 1 & 100.00 & 1 & 100.00 \\
\hline 2 & Hong Kong & 2 & 99.16 & 1 & 100.00 & 1 & 100.00 & 2 & 96.00 & 4 & 90.30 & 3 & 92.80 \\
\hline 3 & Singapore & 3 & 98.55 & 3 & 99.49 & 4 & 97.65 & 3 & 95.00 & 3 & 91.00 & 5 & 89.90 \\
\hline 4 & Switzerland & 5 & 97.14 & 2 & 99.66 & 2 & 98.02 & 4 & 91.92 & 2 & 92.42 & 2 & 93.36 \\
\hline 5 & China & 13 & 89.03 & 18 & 87.76 & 25 & 79.35 & 22 & 77.00 & 23 & 73.30 & 21 & 77.00 \\
\hline 6 & Qatar & 14 & 88.89 & 17 & 88.10 & 13 & 86.72 & 13 & 84.60 & 19 & 77.10 & 10 & 85.50 \\
\hline 7 & Germany & 15 & 88.75 & 13 & 91.59 & 12 & 88.57 & 10 & 85.60 & 6 & 85.80 & 9 & 86.20 \\
\hline 8 & Taiwan & 17 & 87.91 & 14 & 90.48 & 14 & 86.37 & 11 & 85.40 & 13 & 81.20 & 11 & 85.20 \\
\hline 9 & Australia & 19 & 87.06 & 21 & 85.25 & 17 & 84.27 & 18 & 80.50 & 17 & 79.60 & 16 & 80.50 \\
\hline 10 & UK & 20 & 85.62 & 19 & 86.78 & 18 & 83.34 & 19 & 79.90 & 16 & 79.80 & 18 & 79.20 \\
\hline 11 & Malaysia & 22 & 85.17 & 24 & 83.53 & 19 & 83.05 & 14 & 84.10 & 12 & 82.10 & 15 & 83.10 \\
\hline 12 & Japan & 25 & 81.31 & 26 & 82.27 & 26 & 78.72 & 27 & 72.80 & 21 & 73.80 & 24 & 74.50 \\
\hline 13 & Korea & 27 & 80.12 & 29 & 78.65 & 29 & 74.20 & 25 & 73.90 & 26 & 69.70 & 22 & 75.20 \\
\hline 14 & Thailand & 30 & 79.45 & 27 & 80.10 & 28 & 74.68 & 30 & 69.80 & 29 & 65.00 & 27 & 73.00 \\
\hline 15 & India & 44 & 68.77 & 45 & 69.70 & 41 & 65.83 & 44 & 59.50 & 44 & 53.90 & 40 & 59.90 \\
\hline 16 & Philippines & 50 & 64.66 & 41 & 71.80 & 42 & 65.54 & 41 & 60.20 & 42 & 55.00 & 38 & 63.10 \\
\hline
\end{tabular}

Note: Number of participating countries: 63 countries (2018 \& 2017),

61 countries ( $2016 \& 2015) ; 60$ countries ( $2014 \& 2013)$.

(Source: Official Portal MASTIC, Malaysian Science and Technology Information Center, Statistics World Competiveness Yearbook (WCY), 2013-2018). 